\title{
Anal Cancer Pathologic TNM Finding v8
}

National Cancer Institute

\section{Source}

National Cancer Institute. Anal Cancer Pathologic TNM Finding v8. NCI Thesaurus. Code C133767.

A pathologic finding about one or more characteristics of anal cancer, following the rules of the TNM AJCC v8 classification system. 